\title{
Zika virus: A pandemic in progress
}

\author{
Sankalp Yadav ${ }^{1}$, Gautam Rawal ${ }^{2}$, Mudit Baxi ${ }^{3}$ \\ ${ }^{1}$ General Duty Medical Officer-Il, Department of Medicine \& TB, Chest Clinic Moti Nagar, \\ North Delhi Municipal Corporation, New Delhi, India; \\ ${ }^{2}$ Attending Consultant, Respiratory Intensive Care, Max Super Specialty Hospital, \\ Saket, New Delhi, India; \\ ${ }^{3}$ Postgraduate Student, Department of Orthopedics, Sri Aurobindo Medical College and Postgraduate Institute, \\ Indore, Madhya Pradesh, India
}

\section{ABSTRACT}

The world is facing a number of emerging infections. The latest outbreak of Zika virus infection has only added to the suffering. The WHO declared a state of emergency in the affected countries and has issued alarms worldwide. The paucity of literature leading to lack of clear guidelines is one of the most important factors resulting in a higher number of cases. The absence of clinical vaccine and an antiviral drug may prove to be a really grave situation. The present paper throws some light on this new emerging virus that has been known to man since 1947.

Key words: arboviruses, diagnosis, emerging disease, French Polynesia, serum, viruses, Zika virus

\section{INTRODUCTION}

The world is facing a pandemic in progress named Zika virus (ZIKV) infection. The scientific data about this new emerging virus that is known to man since 1947 is still scarce. $^{[1,2]}$ The ZIKV is an arthropod-borne virus belonging to the genus Flavivirus of the family Flaviviridae, and is closely linked to other virus of the same family such as dengue, yellow fever, West Nile, and Japanese encephalitis viruses. ${ }^{[3-6]}$ ZIKV was first isolated from Zika forest in Uganda from a febrile sentinel rhesus monkey and from the mosquito vector, Aedes africanus, in the year 1947 and 1948, respectively. ${ }^{[3,7]}$ These initial isolations were followed by detection of ZIKV in humans, mosquitoes, and other animals in Africa and Asia by virus isolation and serological studies. ${ }^{[3,8-13]}$ On the basis of comprehensive genomic comparison showing different sub-clades, the existence of two main lineages, one African and one Asian lineage of ZIKV have been reported. ${ }^{[14-18]}$ The African lineage is divided into East and West African clusters, some authors described three different lineages (West African, East African, and Asian)..$^{[16-19]}$ The Asian lineage is extending, this lineage emerged in the Pacific and in South America. ${ }^{[17,20-22]}$

\section{Epidemiology and transmission}

Previous studies have demonstrated that ZIKV is endemic to Africa and Southeast Asia. ${ }^{\left[6,{ }^{12]}\right.}$ Till the year 2007 , only 14 cases of ZIKV infection in humans were reported. ${ }^{[6,18]}$ But in the year 2007, an epidemic of ZIKV infection in humans from the Yap, Federated States of Micronesia was reported. ${ }^{[6]}$ A survey of seroprevalence reported that $\leq 70 \%$ of the population had been infected. ${ }^{[5]}$ After that, during 20072013, the few cases of infection with ZIKV reported were in travelers returning from afflicted countries of Africa or Southeast Asia. ${ }^{[23,24]}$

The ZIKV is transmitted primarily by Aedes spp. mosquitoes that are infected. ${ }^{[6,7,12,25,26]}$ Cases have been reported from elsewhere in the world and also from the developed countries that could well be attributed to patients having traveled to the afflicted countries. ${ }^{[6]}$ The scientific data about this virus is sparse and no clear picture about the exact life cycle, transmission, pathology, clinical features, diagnosis, and management is available. However, the recent reports published have thrown some light on the possible transmission, clinical features, diagnosis, and management, but still no 
clear guidelines based on the studies to manage this new emerging virus in the absence of a drug or vaccine are available. $^{[1,33]}$

\section{Clinical presentation}

As per an estimate, about $80 \%$ of persons infected with ZIKV are asymptomatic or mildly symptomatic. ${ }^{[6,28,29]}$ In humans, ZIKV infection is characterized by mild fever $\left(37.8-38.5^{\circ} \mathrm{C}\right)$; arthralgia, mainly of small joints of hands and feet; headache; myalgia, retro-orbital pain; conjunctivitis; and cutaneous maculopapular rash. ${ }^{[6,29]}$ There are other symptoms as described elsewhere and thus, no specific presentation of ZIKV is available. ${ }^{[6]}$ Symptoms usually last from several days to one week and is managed by supportive care. ${ }^{[1]}$ As ZIKV infection is mild, so it can be easily misdiagnosed during the acute (viremic) phase because of nonspecific influenza-like signs and symptoms. Also, in countries where other flaviviruses virus are also present, it is very difficult to diagnose the ZIKV, especially in situations where the viral load is low due to the cross-reactivity of ZIKV antibodies with other flaviviruses. ${ }^{[1]}$ Hospitalization in ZIKV illness is uncommon, and fatalities are rare since the disease is not severe. ${ }^{[30]}$ Hemorrhagic signs have not been reported in ZIKV-infected patients. ${ }^{[5,23,24]}$ However, neurological complications, including Guillain-Barré syndrome, have been observed in suspected cases. ${ }^{[6,31-33]}$ Also, the ZIKV has emerged with a sudden outbreak of cases of microcephaly with a 20 -fold increment in the recent births and has raised alarms. ${ }^{[34-36]}$ The situation in certain countries is so grave that the government officials have advised for postponement of pregnancies till 2018. ${ }^{[37]}$ The evidences of ZIKV being isolated from the amniotic fluid and other specimens of the babies along with a history of travel to an endemic or ZIKV-affected country by a mother, are some of the indicators correlating the cause with the new arbovirus. The reports of higher chances of infection in the third trimester are available, but as per the CDC, pregnant women can be infected with ZIKV in any trimester. $^{[38-40]}$

\section{Diagnosis and management}

Biological confirmation of ZIKV infections is based mainly on the detection of virus RNA in serum by using reverse transcription Polymerase Chain Reaction assays. Although IgM against ZIKV can be detected by ELISA, but this test is not widely available. ${ }^{[1]}$ Thus, in addition to the nonspecific clinical features of infection with ZIKV, laboratory diagnosis is challenging because of low viremia and cross-reactivity of ZIKV antibodies with other flaviviruses, which require confirmation by neutralization assays and thus, making the rapid serologic confirmation difficult. ${ }^{[1]}$ ZIKV has been reported to be isolated from various types of samples such as blood, saliva, urine, semen, amniotic fluid, umbilical cord and so on and thus, further studies aimed at finding a quicker and cheaper diagnostic technique for the ZIKV is warranted. The samples of blood and saliva are really important at the early detection of ZIKV during the stages of acute viremia. ${ }^{[6,19]}$ The role of samples such as saliva is especially important in conditions where other samples are difficult to obtain. ${ }^{[6,41]}$ The virus can also be traced from urine samples after one week of onset of symptoms. ${ }^{[6]}$

The protection from the mosquito bites by avoiding travel to ZIKV-infected countries and control of mosquito vector is the mainstay of the prevention from ZIKV. ${ }^{[42,43]}$ In countries where the per capita income is low and a fraction of the annual budget goes to health, the situation can become really grave. ${ }^{[4-46]}$ Lack of complete knowledge and clearer action plan could lead to a very serious situation and thus, the role of proper dissemination of healthcare information to the general public is very important and all the stakeholders such as the governments, health care providers, and NGOs such as HIFA2015 and so on should play an active and an important role. ${ }^{[47-49]}$

\section{CONCLUSIONS}

The new emerging ZIKV infection in various countries demands actions to be taken at the grassroots level. The current situation is really discouraging as new infections are developing and spreading at a fast pace. If the ZIKV infection spreads widely then it may lead to a lot of hue and cry, especially from Asian countries. The havoc created by other flaviviruses such as dengue, Chikungunya and so on has already resulted in a lot of public health issues and thus, in such a situation, the ZIKV could only result in real chaos. The absence of sufficient literature has led to real concern as there are no clear guidelines for the control of the ZIKV infection.

The role of clinicians, public health officials, non-profit organizations, and high-quality reference laboratories is very important. Extensive research for the development of exact guidelines for control and prevention of this disease is warranted as the ZIKV is still a pandemic in progress. Also, the ease with which the exotic pathogens are transmitting from one continent to another should be studied in detail and methods to control this transmission be developed. There is a need for strong clinical vigilance and epidemiologic and laboratory surveillance systems to detect the spread of infectious diseases. Efforts should be made to increase awareness among the lay public about the virus and protective measures to be taken.

\section{Conflicts of Interest}

None declared. 


\section{REFERENCES}

1. Fauci AS, Morens DM. Zika virus in the Americas - Yet another arbovirus threat. N Engl J Med 2016;374:601-4.

2. Dick GW, Kitchen SF, Haddow AJ. Zika virus. I. Isolations and serological specificity. Trans R Soc Trop Med Hyg 1952;46:509-20.

3. Diallo D, Sall AA, Diagne CT, Faye O, Faye O, Ba Y, et al. Zika Virus Emergence in mosquitoes in Southeastern Senegal, 2011. PLoS ONE 2014;9(10):e109442.

4. Wolfe ND, Kilbourn AM, Karesh WB, Rahman HA, Bosi EJ, Cropp BC, et al. Sylvatic transmission of arboviruses among Bornean orangutans. Am J Trop Med Hyg 2001;64:310-6.

5. Duffy MR, Chen TH, Hancock WT, Powers AM, Kool JL, Lanciotti RS, et al. Zika virus outbreak on Yap Island, Federated States of Micronesia. N Engl J Med 2009;360:2536-43.

6. Gourinat AC, O'Connor O, Calvez E, Goarant C, Dupont-Rouzeyrol M. Detection of Zika virus in urine. Emerg Infect Dis 2015;21:84-6.

7. Haddow AJ, Williams MC, Woodall JP, Simpson DI, Goma LK. Twelve isolations of Zika virus from Aedes (Stegomyia) Africanus (Theobald) taken in and above a Uganda forest. Bull World Health Organ 1964;31:5769.

8. Fagbami AH. Zika virus infections in Nigeria: virological and seroepidemiological investigations in Oyo State. J Hyg (Lond) 1979;83:213-9.

9. Heang V, Yasuda CY, Sovann L, Haddow AD, Travassos da Rosa AP, Tesh RB, et al. Zika virus infection, Cambodia, 2010. Emerg Infect Dis 2012;18:349-51.

10. McCrae AW, Kirya BG. Yellow fever and Zika virus epizootics and enzootics in Uganda. Trans R Soc Trop Med Hyg 1982;76:552-62.

11. Duong V, Vong S, Buchy P. Dengue and other arboviral diseases in South-East Asia. Med Trop (Mars) 2009;69:339-44.

12. Hayes EB. Zika virus outside Africa. Emerg Infect Dis 2009;15:1347-50.

13. Akoua-Koffi C, Diarrassouba S, Benie VB, Ngbichi JM, Bozoua T, Bosson $\mathrm{A}$, et al. Investigation surrounding a fatal case of yellow fever in Cote d'Ivoire in 1999. Bull Soc Pathol Exot 2001;94:227-30.

14. European Centre for Disease Prevention and Control. Rapid risk assessment: Zika virus epidemic in the Americas: potential association with microcephaly and Guillain-Barré syndrome. 10 December 2015. ECDC, Stockholm; 2015. Available from URL: http://ecdc.europa.eu/en/ healthtopics/zika_virus_infection/factsheet-healthprofessionals/Pages/ factsheet_health_professionals.aspx. Last accessed 2016 on February 1.

15. Kuno G, Chang GJ, Tsuchiya KR, Karabatsos N, Cropp CB. Phylogeny of the genus Flavivirus. J Virol 1998;72:73-83.

16. Faye O, Freire CC, Iamarino A, Faye O, de Oliveira JV, Diallo M, et al. Molecular evolution of Zika virus during its emergence in the 20(th) century. PLoS Negl Trop Dis 2014;8:e2636.

17. Haddow AD, Schuh AJ, Yasuda CY, Kasper MR, Heang V, Huy R, et al. Genetic characterization of Zika virus strains: geographic expansion of the Asian lineage. PLoS Negl Trop Dis 2012;6:e1477.

18. Musso D, Nhan T, Robin E, Roche C, Bierlaire D, Zisou K, et al. Potential for Zika virus transmission through blood transfusion demonstrated during an outbreak in French Polynesia, November 2013 to February 2014. Euro Surveill 2014;19:pii:20761.

19. Lanciotti RS, Kosoy OL, Laven JJ, Velez JO, Lambert AJ, Johnson $\mathrm{AJ}$, et al. Genetic and serologic properties of Zika virus associated with an epidemic, Yap State, Micronesia, 2007. Emerg Infect Dis 2008;14:1232-9.

20. Cao-Lormeau VM, Roche C, Teissier A, Robin E, Berry AL, Mallet HP, et al. Zika virus, French polynesia, South pacific, 2013. Emerg Infect Dis 2014;20:1085-6.

21. Campos GS, Bandeira AC, Sardi SI. Zika virus outbreak, Bahia, Brazil. Emerg Infect Dis 2015;21:1885-6.

22. Zanluca C, de Melo VC, Mosimann AL, Dos Santos GI, Dos Santos CN, Luz K. First report of autochthonous transmission of Zika virus in Brazil. Mem Inst Oswaldo Cruz 2015;110:569-72.
23. Kwong JC, Druce JD, Leder K. Zika virus infection acquired during brief travel to Indonesia. Am J Trop Med Hyg 2013;89:516-7.

24. Foy BD, Kobylinski KC, Chilson Foy JL, Blitvich BJ, Travassos da Rosa A, Haddow AD, et al. Probable non-vector-borne transmission of Zika virus, Colorado, USA. Emerg Infect Dis 2011;17:880-2.

25. CDC. Zika virus. Atlanta, GA: US Department of Health and Human Services, CDC; 2016. Available from URL: http://www.cdc.gov/zika/ index.html. Last accessed 2016 on February 1.

26. Wong PS, Li MZ, Chong CS, Ng LC, Tan CH. Aedes (Stegomyia) albopictus (Skuse): a potential vector of Zika virus in Singapore. PLoS Negl Trop Dis 2013;7:e2348.

27. Bogoch II, Brady OJ, Kraemer MUG, German M, Creatore MI, Kulkarni MA, et al. Anticipating the international spread of Zika virus from Brazil. The Lancet 2016;387:335-6.

28. Petersen EE, Staples E, Meaney-Delman D, Fischer M, Ellington SR, Callaghan WM, et al. Interim Guidelines for Pregnant Women During a Zika Virus Outbreak - United States. MMWR Morb Mortal Wkly Rep 2016;65;30-3.

29. Marcondes CB, de Fátima Freire de Melo Ximenes M. Zika virus in Brazil and the danger of infestation by Aedes (Stegomyia) mosquitoes. Rev. Soc. Bras. Med. Trop Dec 22, 2015. [Epub ahead of print].

30. Staples JE, Dziuban EJ, Fischer M, Cragan JD, Rasmussen SA, Cannon MJ, et al. Interim guidelines for the evaluation and testing of infants with possible congenital Zika virus Infection - United States, 2016. MMWR Morb Mortal Wkly Rep 2016;65:63-7.

31. Oehler E, Watrin L, Larre P, Leparc-Goffart I, Lastere S, Valour F, et al. Zika virus infection complicated by Guillain-Barré syndrome - case report, French Polynesia, December 2013. Euro Surveill 2014;19:20720.

32. Mallet HP, Vial AL, Musso D. Bilan de lépidémie à virus Zika en Polynésie française, 2013-2014. Zika virus outbreak in French Polynesia, 20132014. Bulletin d'information sanitaire, épidémiologique et statistique 2015;13:1-5.

33. Ioos S, Mallet HP, Leparc Goffart I, Gauthier V, Cardoso T, Herida M. Current Zika virus epidemiology and recent epidemics. Med Mal Infect 2014;44:302-7.

34. European Centre for Disease Prevention and Control. Rapid risk assessment: Zika virus epidemic in the Americas: potential association with microcephaly and Guillain-Barré syndrome. Stockholm, Sweden: European Centre for Disease Prevention and Control; 2015. Available from URL: http://ecdc.europa.eu/en/publications/Publications/zikavirus-americas-association-with-microcephaly-rapid-risk-assessment. pdf. Last accessed 2016 on February 1.

35. Oliveira Melo AS, Malinger G, Ximenes R, Szejnfeld PO, Alves Sampaio S, Bispo de Filippis AM. Zika virus intrauterine infection causes fetal brain abnormality and microcephaly: tip of the iceberg? Ultrasound Obstet Gynecol 2016;47:6-7.

36. Hennessey M, Fischer M, Staples JE. Zika virus spreads to new areasRegion of the Americas, May 2015-January 2016. MMWR Morb Mortal Wkly Rep 2016;65:1-4.

37. Reuters Staff. El Salvador Urges Against Pregnancies Until 2018 as Zika Virus Spreads. Available from URL: http://www.scientificamerican.com/ article/el-salvador-urges-against-pregnancies-until-2018-as-zika-virusspreads/. Last accessed 2016 on February 1.

38. Brazil Ministry of Health. Ministry of Health confirms relationship between Zika virus and microcephaly. Press release, November 28, 2015. Available from URL: http://portalsaude.saude.gov.br/index.php/cidadao/ principal/agencia-saude/21014-ministerio-da-saude-confirma-relacaoentre-virus-zika-e-microcefalia. Last accessed 2016 on February 1.

39. CDC. CDC health advisory: recognizing, managing, and reporting Zika virus infections in travelers returning from Central America, South America, the Caribbean and Mexico. Atlanta, GA: US Department of Health and Human Services, CDC; 2016. Available from URL: http:// emergency.cdc.gov/han/han00385.asp. Last accessed 2016 on February 1. 
40. Besnard M, Lastere S, Teissier A, Cao-Lormeau V, Musso D. Evidence of perinatal transmission of Zika virus, French Polynesia, December 2013 and February 2014. Euro Surveill 2014;19:13-6.

41. Musso D, Roche C, Nhan TX, Robin E, Teissier A, Cao-Lormeau VM, et al. Detection of Zika virus in saliva. J Clin Virol 2015;68:53-55.

42. CDC. Travel notices. Atlanta, GA: US Department of Health and Human Services, CDC; 2016. Available from URL: http://wwwnc.cdc.gov/travel/ notices. Last accessed 2016 on February 1.

43. Nasci RS, Wirtz RA, Brogdon WG. Protection against mosquitoes, ticks, and other arthropods. In: CDC health information for international travel, 2016. New York, NY: Oxford University Press; 2015:94-9. Available from URL: http://wwwnc.cdc.gov/travel/yellowbook/2016/ the-pre-travel-consultation/protection-against-mosquitoes-ticks-otherarthropods. Last accessed 2016 on February 1.
44. Yadav S, Rawal G. Counterfeit drugs: problem of developing and developed countries. Int J Pharmceut Chem Anal 2015;2:46-50.

45. Yadav S, Rawal G. Swine flu-Have we learnt any lesson from the past? Pan Afr Med J 2015;22;118.

46. Yadav S, Rawal G, Baxi M. Plagiarism-a serious scientific misconduct. Int J Health Sci Res 2016; 6(2):364-366.

47. Yadav S, Rawal G. Healthcare information for all-Is it achievable? Int J Sci Res Rev 2015;4:101-5.

48. Yadav S, Rawal G. The HIFA and the HealthPhone: Laying the foundation for combating malnutrition in India. Int J Health Sci Res 2015;5:368-71.

49. Yadav $S$, Rawal G. Self-medication practice in low income countries. Int J Pharmaceut Chem Anal 2015;2:139-42.

How to cite this article: Yadav S, Rawal G, Baxi M. Zika virus: A pandemic in progress. J Transl Intern Med 2016; 4: 42-5. 